\title{
Afrikaans Learner's Dictionaries for a Multilingual South Africa
}

\author{
R.H. Gouws, Department of Afrikaans and Dutch, \\ University of Stellenbosch, South Africa
}

\begin{abstract}
Dictionaries have to be compiled in accordance with the specific needs and demands of a well-defined target user. Within the multilingual and multicultural South African society dictionaries should be aimed at the needs of the different groups of language learners. This article discusses aspects of Afrikaans learner's dictionaries. The emphasis is on the need and criteria for such dictionaries, the typical target user and on the nature of the macro- and microstructuraI information to be included. In a leamer's dictionary the information should be presented in such a way that it can be retrieved without problems. Attention is given to various access structures employed to enhance the retrievability of information. It is argued that a restricted and simplified microstructure leads to a decrease in the density of information but to an increase in the explicitness and retrievability. The article proposes a different approach to the inclusion of certain types of encyclopedic information in learner's dictionaries.
\end{abstract}

Keywords: ACCESS STRUCTURES, ADDRESSING, DENSITY OF INFORMATION, ENCYCLOPEDIC INFORMATION, EXPLICITNESS, ILLUSTRATIVE EXAMPLES, LEARNER'S DICTIONARY, MACROSTRUCTURE, METALEXICOGRAPHY, MICROSTRUCTURE, PICTORIAL ILLUSTRATIONS, RETRIEVABILITY, SIMPLICITY, TARGET USER, TRANSLATION EQUIVALENTS

Opsomming: Afrikaanse aanleerderwoordeboeke vir 'n meertalige SuidAfrika. Woordeboeke moet saamgestel word met inagneming van die behoeftes en eise van 'n spesifieke teikengebruiker. Binne die multikulturele en meertalige Suid-Afrika moet daar vir die behoeftes van verskillende groepe taalaanleerders voorsiening gemaak word. Hierdie artikel bespreek aspekte van Afrikaanse aanleerderwoordeboeke. Die klem is op die behoefte aan en kriteria vir sulke woordeboeke, op die teikengebruiker en ook op die makro- en mikrostrukturele inligting wat in so ' $n$ woordeboek opgeneem moet word. In 'n aanleerderwoordeboek moet inligting op so ' $n$ manier aangebied word dat dit probleemloos herwin kan word. Aandag word gegee aan toegangstrukture wat gebruik word om die herwinbaarheid van inligting te verhoog. Daar word aangevoer dat ' $n$ beperkte en vereenvoudigde mikrostruktuur tot ' $n$ verlaging in die inligtingsdigtheid lei maar tot ' $n$ verhoging in die eksplisietheid en herwinbaarheid. 'n Ander benadering word voorgestel vir die opname van sekere tipes ensiklopediese inligting in aanleerderwoordeboeke.

Sleutelwoorde: AANLEERDERWOORDEBOEK, ADRESSERING, EENVOUD, EKSPLISIETHEID, ENSIKLOPEDIESE INLIGTING, HERWINBAARHEID, ILLUSTRASIEPRENTE, INLIGTINGSDIGTHEID, MAKROSTRUKTUUR, METALEKSIKOGRAFIE, MIKROSTRUKTUUR, 
TEIKENGEBRUIKER, TOEGANGSTRUKTUUR, VERTAALEKWIVALENTE, VOORBEELDMATERIAAL

\section{Introduction}

Within the existing theoretical discussions of lexicographical issues much emphasis is placed on the so-called "user perspective". It is an accepted fact that every dictionary has to be compiled in accordance with the specific needs and demands of a well-defined target user. According to Diab (1990: 17) traditional lexicography concerned itself with the problems of the lexicographer instead of the needs of the dictionary user. It is important for any lexicographer to be needs-sensitive in the planning and compilation of a dictionary.

The latest versions of a general dictionary typology focus on the importance of learner's dictionaries and on their unique contribution in the teaching of a foreign language. The monolingual leamer's dictionary, which traditionally dominated this category, directs its pedagogical approaches at any nonnative learner of the target language. Herbst (1990: 1379) states that a learner's dictionary is a synchronic monolingual dictionary and Snell-Hornby (1987: 159) refers to the absence of a bilingual dictionary designed to meet the specific needs of learners. Yet, the last decade witnessed the emergence of bilingual learner's dictionaries and an increased awareness of their functional value. However, much research is still needed to identify and formulate the theoretical principles to which these dictionaries should adhere and to determine their linguistic and pedagogical scope.

These changing perspectives of learner's dictionaries and the emphasis on the function of the bilingual learner's dictionary will have definite implications for the South African lexicographical endeavours, adding to the variety of exciting challenges that face both lexicographer and linguist in this multicultural and multilingual society.

\section{South African learner's dictionaries}

In spite of a well-established lexicographical tradition and a representative typological variety the South African dictionary collection lacks learner's dictionaries. This applies to both Afrikaans and the nine indigenous African languages used in South Africa. As far as English is concerned the existing British learner's dictionaries are used extensively. The general availability of these dictionaries and the comprehensive way in which they are employed in language teaching accentuate the need for learner's dictionaries for Afrikaans and the other indigenous languages. 


\section{Towards Afrikaans learner's dictionaries}

In a multilingual society learner's dictionaries are needed to grant members of the different speech communities access to the other languages. In the planning and compilation of South African dictionaries scant attention was given to the position, function and importance of leamer's dictionaries. This approach has changed. The lack of Afrikaans learner's dictionaries had been identified as a major void in the typology of dictionaries, cf. Alberts and Mtintsilana (1988) and Otto (1989), and suggestions were made to rectify the situation. These suggestions resulted in a comprehensive project aimed at the compilation of a series of Afrikaans learner's dictionaries with the compilation of an Afrikaans monolingual learner's dictionary as a first step. This dictionary, Basiswoordeboek van Afrikaans, has since then been completed and is due to be published later this year.

Basiswoordeboek van Afrikaans (henceforth abbreviated as BA) is aimed at the needs of non-native learners of Afrikaans but should also be of help to native speakers, especially at school level. BA has been compiled in such a way that it could form a basis for a wide-ranging selection of bilingual learner's dictionaries in which Afrikaans will feature alongside the nine indigenous languages. The macrostructural selection of BA endeavours to display the core vocabulary of Afrikaans, adhering to a criterion discussed by Kühn (1990: 1352) that it is sensible not to employ the full vocabulary of a language in teaching it as a foreign language, but rather to rely on a representative and functional selection of lexical items. The lemma selection of BA will form the macrostructural basis of the Afrikaans as source language component of the bilingual dictionaries.

The compilation of an Afrikaans-English learner's dictionary had not been envisaged as part of this project. The motivation for this decision lay in the extent and nature of the bilingual dictionaries presently available and the needs of the dictionary user. Since 1925 Afrikaans and English have been the two official languages of South Africa. This status of these two languages has led to the compilation of a variety of Afrikaans-English dictionaries. The intended target user of these dictionaries is the Afrikaans/English speaking bilingual South African. The fact that this target user lives in an environment where he is in daily contact with both languages has had an influence on both the macrostructure and the addressing in the dictionary articles. Bilingual Afrikaans/English dictionaries like Tweetalige Woordeboek/Bilingual Dictionary and Groot Woordeboek/Major Dictionary are actually aimed at a sophisticated user of both Afrikaans and English and they are not instruments in the hand of a learner. Yet, the availability, authority and comprehensiveness of these dictionaries made lexicographers and linguists less aware of the need for a bilingual Afrikaans-English learner's dictionary. Although these dictionaries may perhaps suffice the needs of a wide-ranging spectrum of language users they do not comply with the demands of the learner and therefore their existence 
should not prohibit the compilation of bilingual learner's dictionaries. Since the start of this learner's dictionary project and independent thereof, another publishing house has recently produced a bilingual Afrikaans-English learner's dictionary. This dictionary Tweetalige Aanleerderswoordeboek/Bilingual Learner's Dictionary (henceforth abbreviated as TAW) will play an important pedagogical role. In spite of the initial lack of interest in an Afrikaans/English learner's dictionary the publication of TAW stresses once again the validity of SnellHornby's belief (1987: 159) that the lack of bilingual learner's dictionaries results in the foreign learner falling back on traditional general-purpose concise or pocket dictionaries. These dictionaries, claims Snell-Hornby, are the type of reference book least suitable as an aid to language learning. This also applies to the situation in South Africa.

During the work on BA the project committee was approached by a publishing house to support the publication of an Afrikaans/Zulu bilingual learner's dictionary. The manuscript of this dictionary had already been completed and although it did not correspond with the editorial policy proposed for the dictionaries in this series, the need for an Afrikaans/Zulu dictionary prompted the committee to give its support to the publication of Afrikaans/Zoeloe Woordeboek met Engelse vertalings.

Following the completion of BA the rest of the project can continue with the compilation of bilingual dictionaries for Afrikaans and Northern Sotho, Southern Sotho and Tswana respectively as the following target publications.

\section{Criteria for a monolingual Afrikaans learner's dictionary}

Before the compilation of any dictionary the potential target user, his lexicographical needs and abilities have to be identified. Not only the macrostructural selection but also the microstructural treatment of lemmas and the addressing should be determined by the target user profile. As a monolingual Afrikaans learner's dictionary BA had to be compiled in such a way that it could be used in the compilation of a variety of bilingual learner's dictionaries involving Afrikaans and the indigenous African languages. Due to its unique assignment to function both as independent dictionary and as basis for a series of other dictionaries, the specific needs, demands and abilities of speakers from a broad linguistic and cultural spectrum had to be taken into account in the planning and compilation of this dictionary.

\section{The target user of a monolingual Afrikaans learner's dictionary}

According to Hansen (1990: 1) the selection and representation of information in a dictionary should be determined by the needs of users and the ordering of the information should be done in such a way that the user can find the 
answers to his questions in the quickest possible time. To achieve maximum retrievability the macrostructure of a learner's dictionary has to include access structures to overcome possible hedges in the search for a specific lemma, but retrievability also demands a microstructural display which is not only relevant to the linguistic and pragmatic needs of the user but also enhances an unbiased and neutral representation of cultural and ideological values. This point is especially applicable where the target users come from a multilinguistic and multicultural environment.

The potential users of Afrikaans learner's dictionaries represent a cultural and linguistic heterogeneous community. Besides native speakers of Afrikaans who might need to use the dictionary it will be used by speakers of various European languages, speakers of South African English and speakers from the nine indigenous African languages. The lexicographer cannot satisfy all these users on an equal basis and his decisions in the planning and structuring of the learner's dictionary have to be motivated by the sociolinguistic profile of the most typical target user.

The lexicographer of an Afrikaans learner's dictionary has to negotiate the reality of target users with opposing cultural and ideological views. The dictionary may not take a biased stand but the macrostructural selection as well as the treatment of the lemmas have to maintain a neutral attitude towards culture and ideology specific items. According to Carter (1983: 174) words contain and conceal ideology. The political history of South Africa had a far-reaching influence on language and especially on Afrikaans and its lexicon, and it has created a lexical stigmatization. This stigmatization has a varying occurrence because some words have acquired a general taboo in all the different ideological communities whereas other words have only been the target of a restricted taboo. The lexicographer has to be aware of the ideological and symbolic values and has to exercise the necessary sensitivity.

The policy of apartheid, that Afrikaans word included in almost every nonAfrikaans dictionary, was formulated by the National Party which used to be the political home of predominantly Afrikaans speaking white South Africans. As a result Afrikaans had for years been regarded as the language of the oppressor. Many Afrikaans words became stigmatized due to their occurrence in the apartheid terminology. Afrikaans dictionaries had not always been sensitive enough to the symbolic value of these items, and their lexicographical treatment has estranged many potential speakers from Afrikaans. Any Afrikaans dictionary compiled today, and especially a leamer's dictionary aimed at the promotion of Afrikaans amongst speakers of other South African languages, has to take linguistic affirmative action in order to rectify the old perception and to deideologize Afrikaans. Although dictionaries have to be regarded as sources of linguistic information, the scope of an Afrikaans learner's dictionary in South Africa exceeds the limits of linguistic lexicography by becoming also a cultural and a depoliticizing instrument. This additional 
function is a direct result of the sociolinguistic, cultural and political profile of the target users.

The decision of the project committee to use the lemma selection of BA as a basis for the bilingual dictionaries dealing with Afrikaans and the African languages is also influenced by the sociolinguistic profile of the target groups. Because the monolingual dictionary as well as the bilingual dictionaries are primarily aimed at users learning Afrikaans as a third or fourth language, the vocabulary needs are of a restricted nature and more or less the same vocabulary can be used throughout the series.

\section{The macrostructure of an Afrikaans learner's dictionary}

The compilation of a series of Afrikaans learner's dictionaries will make Afrikaans more accessible to the whole South African community and will promote Afrikaans amongst non-Afrikaans speaking South Africans. The linguistic situation in South Africa compels the lexicographer to design an Afrikaans learner's dictionary for target users leaming Afrikaans as a second, third or even fourth language. As a pedagogical instrument the Afrikaans learner's dictionary has to employ a variety of methods to deal with the often conflicting demands of the teaching of a foreign language to such a diverse target group. This has definite implications for both the macro- and the microstructure and emphasizes the need for clarity and userfriendly access structures.

From a macrostructural perspective it is important that the lemma selection has to be restricted to a fairly simple level; even simpler than the level of those learner's dictionaries compiled for users learning a second language. Consequently BA's lemma selection could not have been done on a random basis but the lexicographers had to adhere to fixed selection criteria, with usage frequency as a dominating factor. Relying on frequency lists, transcriptions of oral interviews, general usage in papers, television programs, etc., a selection of core vocabulary items was made.

\section{The microstructure of an Afrikaans learner's dictionary}

One of the major aims of a learner's dictionary is to assist the user in achieving a certain degree of communicative competence. By creating a well-motivated macrostructure the lexicographer knows the user should be able to find the most typical words he is to encounter in the target language. However, communicative competence relies on much more than a sound lemma selection. The microstructural treatment of each lemma has to enable the user to cultivate the skills necessary for the actual usage of the word in real communication. Where the macrostructure offers the user access to a selected part of the vocab- 
ulary, the microstructure offers access to the linguistic characteristics of those items. This access should be given in an unambiguous way to provide the easiest possible transfer of information. According to Ayto (1984:50) a word should be defined using words simpler than itself. This belief of simplicity in the definition is widely respected. Ayto goes further by stating that the main motive behind adopting this notion of "greater simplicity" is to maximize the user's chances of understanding the definition.

A notion of greater simplicity should be a governing principle in learner's dictionaries and should not only apply to the definition but to every entry in the article. The learner's dictionary may not only differ in name from other dictionaries. According to Herbst (1990: 1379) the rationale behind a general learner's dictionary is the insight that the foreign users' demands on a dictionary differ fundamentally from those of a native speaker. Therefore the lexicographer's product intended for the foreign user has to differ fundamentally from the one intended for the native speaker.

Because the lexicographer may rely on neither the linguistic intuition nor any presumed dictionary skills of the target user, attempts to achieve the necessary simplicity have to depend on the structure and contents of the article. Communicative success in learner's dictionaries requires an interaction of the principle of simplicity and various pedagogical methods. One such method is the attempt to enhance the retrievability of the microstructural information by introducing a variety of clearly defined access structures in the article. This method coincides with an attempt at greater explicitness. Although macrostructural access can easily be ensured by a consistent ordering according to the alphabetical system, microstructural access demands the inclusion of additional entries specifically aimed at guiding the user to the given information. Following Hausmann and Wiegand (1989: 329) this type of access structure is known as the "inner access structure". A second pedagogical method to enhance the retrievability is the decreasing of the density of information in the article.

\section{Enhancing the retrievability of information}

\section{The utilization of access structures}

Dictionaries do not only convey information by way of language signs and codes but also by way of typographical conventions. These codes and typographical markers have to ensure an optimal transfer of information, but quite often they add to the complexity of the microstructure and impede the successful interpretation of the lexicographical text. The typical user of an Afrikaans learner's dictionary, and this can also apply to learner's dictionaries in general, is often unsophisticated in the skills of dictionary use, and he relies on the dictionary for instant assistance - without being obliged to follow cross- 
references to other parts of the dictionary; especially not coded crossreferences which he still has to decode to acquire the needed help. A learner's dictionary has to respond to the need for an instant retrieval of information by inventing and using the necessary access structures.

The utilization of access structures has to be employed in tandem with the principle of greater simplicity. This complementary combination should aim to decrease typographical markers and other entries that add to the complexity of the article and it should introduce innovative conventions aimed at an unambiguous guiding towards every information category in the article.

One type of inner access structure employed on a regular basis in BA, but not unique to $\mathrm{BA}$, is the display of usage and semantic notes as part of the article of a lemma. These notes can either refer to the lemma or to a specific microstructural entry, and the position of these notes in the articles gives a clear indication of their scope. The usage or semantic notes are placed in a square frame and clearly distinguished from the other entries. This square frame is an access structure pointing unambiguously at a specified entry type. Afrikaans has a spectrum of varieties ranging from the formal and standard to the colloquial and dialectal. Although a learner's dictionary like BA focuses on the core vocabulary which consists largely of elements from the standard variety it also accommodates non-standard, informal and colloquial items. The way in which these items deviate from the neutral standard usage has to be marked: either by stylistic labelling or by usage notes. Both labels and clearly identifiable usage notes can be regarded as access structures aimed at the enhancement of the communicative and pedagogical function of a learner's dictionary. An example of one of these access structures in BA can be found in the article of the lemma aanhou ("continue"/"continuously"):

"Opmerking: Aanhou se gebruik as bywoord is beperk tot informele spreektaal" (Note: The use of aanhou as an adverb is restricted to informal oral usage.)

One of the major problems dictionary users experience with access structures and microstructural coding, is the complexity created by these entries. The first edition of the Longman Dictionary of Contemporary English (LDOCE) made extensive use of a system of grammatical coding. These codes are relevant and they convey important information by indicating the grammatical subsets to which a specific lemma belongs. The code letter $T$ indicates that a lemma is a transitive verb with one object, and $T 1$ indicates that such a transitive verb can be followed by one or more nouns or pronouns. Although these codes help with the retrieval of information, they convey it in an implicit way because the information identified by the code letter is not explicitly given in the article. The user has to turn to the back matter of the dictionary to get a key to the different codes. Inner access structures have to refer to information explicated in the article itself. To achieve communicative success a learner's dictionary 
should avoid unnecessary cross-references based on a system in which the interpretation of an article depends on information given elsewhere in the dictionary. Inner access structures are functional when they are anchored in the article and used to mark article internal information. They should point at the article itself and should not link the article with information given in other sections of the dictionary.

In TAW the lexicographers have opted for a limited number of access structures but they all have clearly identifiable internal referents. The limited use of access structures has increased the functionalism of the ones employed and it has improved the microstructural simplicity. Because TAW is a bilingual dictionary the focus of each article is on the translation equivalent(s) and the illustrative examples. TAW conveys this information in an uninterrupted way by deviating from the typical dictionary pattern to give information on word class, morphology and pronunciation immediately after the lemma. This microstructural representation establishes a new approach in learner's dictionaries. In any dictionary the lemma has to be seen as the head of the article. The microstructure can contain a variety of information types and in general monolingual and bilingual dictionaries, as well as in learner's dictionaries, the articles are characterized by a system of lemmatic-addressing because the microstructural information is typically directed at the lemma (cf. Hausmann and Wiegand 1989: 328).

Due to the hierarchical character of the microstructure the prominence of the first entries gives them a position of major focus while the last entries receive far less focus. This should influence the organization of information in the dictionary. Being familiar with the specific typological criteria a lexicographer knows what the priority of his dictionary is and which entry should receive the most emphasis. This should prompt him to position the entry of high priority in a focus slot of the article, i.e. as the first lemmatic-address and therefore in the highest position in the microstructural hierarchy. The lexicographers of TAW regard the translation equivalent(s), followed by the applicable illustrative examples as their entries of highest priority and consequently these entries are placed in the position of major focus:

"moeilik 1 difficult It's difficult to feed a baby that won't sit still. Dis moeilik om 'n baba te voer wat nie wil stilsit nie. 2 hard Tough meat is hard to chew. Dis moeilik om taai vleis te kou. 3 stiff The examination was so stiff that half the class failed. Die eksamen was so moeilik dat die helfte van die klas gesak het. ..."

Word class information is included but well down in the hierarchy. However, due to the traditional focus position of word class indication TAW does not give a neutral treatment of this entry but marks its occurrence with an access structure: a small rectangle preceding the word class entry. On a similar basis another information type, collocations and short expressions, are marked with 
a small diamond. If applied consistently these access structures can guide the user so that he can retrieve a specific information type as quickly and successfully as possible. The new Oxford Advanced Learner's Dictionary gives a fine display of the correct and functional use of this type of inner access structures. However, lexicographers should try to limit these access structures because if they employ too many it could easily become confusing. This could have similar disadvantages as a comprehensive system of grammatical coding where all the codes are explained in the front or back matter and the user has to turn to these sections to retrieve the information he is expecting to find in the alphabetical section of the dictionary.

\section{Greater explicitness}

As mentioned above the utilization of inner access structures coincides with an attempt at greater explicitness. One dominant feature of a leamer's dictionary should be the clear and explicit way in which it displays its information. This implies that accessibility is enhanced by entries which offer a direct information transfer. The application of this principle has to activate a reconsidering of the use of abbreviations as microstructural entries. Not only the coded transfer of grammatical information, as given in LDOCE1, should be reconsidered but also the use, in many leamer's dictionaries, of abbreviations for word classes. For the average user of an Afrikaans learner's dictionary abbreviations like $n w$. ("naamwoord", noun), ww. ("werkwoord", verb), nwsk. ("neweskikker", coordinator), etc. has much less value than their unabbreviated equivalents. In TAW this principle is applied and the word class is given as an unabbreviated entry.

Greater explicitness combined with a better chance of retrieving information can be acquired by abolishing the system of indicating morphological information, e.g. plurals, diminutives and past tense, by only listing the applicable suffix. Instead of the entries:

$$
\text { "domino ( } p l \text {-es)" }
$$

the lexicographer will do well to give an explicit presentation of the plural form:

$$
\text { "domino (pl dominoes)". }
$$

Such an approach enables the user to gain direct and instant access to the information he needs without the possibility of a wrong interpretation of the system followed in the dictionary. This principle of explicitness is already in use in the Collins COBUILD English Language Dictionary and adds to the userfriendliness of this dictionary. In BA the same principle is also applied and expanded. The lexicon of Afrikaans includes a wide variety of particle verbs. 
The mastering of these verbs confronts the foreign learner of Afrikaans with some real problems. Particle verbs have a diverse occurrence in Afrikaans. The verb aandring ("insist") can be used to explain the typical pattem of Afrikaans particle verbs.

Hy dring aan op ' $n$ verskoning. ("He insists on an apology")

Hy het aangedring op ' $n$ verskoning. ("He insisted on an apology")

Hy sal aandring op ' $n$ verskoning. ("He will insist on an apology")

Om aan te dring op ' $n$ verskoning. ("To insist on an apology")

In the treatment of particle verbs $\mathrm{BA}$ gives this type of information as clear as possible. The article of aandring gives evidence of this approach:

"aandring (dring aan, sal aandring, het aangedring, om aan te dring) ..."

Further on in the article examples are given to illustrate each one of these occurrences of the particle verb. By aiming at greater explicitness BA tries to provide the kind of information needed by typical foreign users of Afrikaans. This explicit way of treating some grammatical aspects of the particle verb enhances the chance of an instant retrieval of information, but it also prevents unnecessary mistakes in the communication process. This approach is adopted because BA will primarily be used as an instrument in the teaching of language.

\section{Decreasing the density of information}

Simplicity and explicitness can be regarded as two of the cornerstones of communicative and pedagogical success in a dictionary. Although both these ideals can be met by employing functional inner access structures, the lexicographer of a learner's dictionary will do well to utilize additional methods to achieve his purpose. One such method is to evaluate and decrease the density of information accommodated in the dictionary.

According to Hausmann (1989: 982) the density of information of a dictionary is the quantitive relation between the macro- and microstructure. An increase in the microstructure of a specific dictionary without changing the macrostructure implies an increase in the density of its information. A dictionary can be macro- or micro-orientated or it could maintain an equality in the macrostructural and microstructural richness.

Hansen (1990: 96) refers to the tendency in the present-day lexicographical practice to increase the density of information by making the articles more compact. Due to space restrictions lexicographical treatment often relies on an implicit transfer of information. An example of an implicit information transfer in a general bilingual dictionary can often be found in the listing of transla- 
tion equivalents. In the Afrikaans-English bilingual dictionary Groot Woordeboek/Major Dictionary the Afrikaans verb beslis gets the following translation equivalents:

"settle, determine, decide; award, adjudicate; conclude".

The implication of this presentation is that the lemma is a polysemous lexical item with three different polysemous senses. This can be deduced from the occurrence of the semi-colons in the list of translation equivalents. Commas are used to separate translation equivalents which are synonyms, and semi-colons separate translation equivalents representing different polysemous senses of the lemma. The relation of synonymy holding between award and adjudicate is not explicitly stated but it is implied by the system used in the dictionary. Implicit presentations increase the density of information; not only because it adds to the quantity of information categories accommodated in the dictionary but also because it impedes instant retrievability. In a dictionary with a high density of information one entry can of ten represent more than one information category (cf. Hansen 1990: 96). In the above-mentioned example the nonalphabetical ordering of the synonyms award and adjudicate implies that the first translation equivalent has a higher usage frequency than the second. Likewise the ordering of the equivalents representing the different polysemous senses of the lemma implies that "settle" is a more dominant sense of beslis than "award". One entry contains more than one type of information and this leads to an ever increasing density of information. Although a high density of information saves space it demands much more from the linguistic and lexicographical foreknowledge of the user. Hansen (1990: 96) states that a higher density of information decreases the explicitness of a dictionary.

The entries settle and determine in the article of beslis differ with regard to their addressing. Settle is given as a translation equivalent of the lemma and therefore it has a lemmatic address. Although determine is also presented as a translation equivalent of the lemma, it has an additional addressing because it is presented as a synonym of settle. In this function determine has a nonlemmatic address and represents a type of sub-addressing. The use of lemmatic and non-lemmatic addressing in one article creates topic switching because each non-lemmatic address is a new topic within the article (Hausmann and Wiegand 1989: 329). Topic switching inevitably increases the density of information as well as the complexity of a dictionary article.

\section{Bidirectional orientation}

In his discussion of the notion "density of information" and the relation between the macro- and microstructure of a dictionary Hausmann (1989: 982) argues that learner's dictionaries are characterized by their microstructural ori- 
entation. This means that their microstructure is richer than their macrostructure. This approach coincides with that of Jehle (1990: 11). According to Jehle the compilation of a monolingual dictionary for foreign users requires the application of scientific findings of modem linguistics to enable the user the optimal utilization of information regarding phonetics, syntax, semantics and pragmalinguistics. Jehle's perspective favours a microstructural orientation in a learner's dictionary. The application of both Hausmann's and Jehle's suggestions will not only enrich the microstructure but will inevitably lead to an increase in the density of information, a decrease in explicitness and a less friendly source of information for the foreign leamer. In a leamer's dictionary the lexicographer should endeavour to restrict the microstructure to such an extent that the retrieval of information is not impeded by a high degree of information density.

When deciding on the density of information of a specific dictionary, the lexicographer once again has to consider the needs and skills of his target user. Quite often in a leamer's dictionary it may be better not to maintain a rigid system but to treat each lemma according to the specific information need. Zgusta (1989: 7) argues that a modular dictionary with variable density of information could be the solution to a lot of these problems.

In an attempt to help the learner, the Afrikaans learner's dictionaries TAW and $\mathrm{BA}$ are not microstructural orientated but they try to maintain a definite balance between the macro- and microstructure by adopting a double or bidirectional orientation. The treatment of lemmas are aimed at the most typical information needs of the target users: a motivated vocabulary selection and a limited collection of microstructural elements. As a descriptive monolingual dictionary BA focuses on the meaning of the lemmas whereas the bilingual TAW puts its emphasis on the translation equivalents.

\section{A restricted and simplified microstructure}

In the multilingual South Africa the typical user of a monolingual Afrikaans learner's dictionary is primarily interested in the meaning of the lemma and in its actual use. BA's microstructure is directed at this need and ignores a variety of other information categories like pronunciation and etymology. It also eschews a too detailed analysis of the information categories which are included. In her comments on the Warlpiri dictionary project, Wierzbicka (1983: 135) argues that the Warlpiri dictionary, and the same criteria apply to an Afrikaans leamer's dictionary, should not contain definitions that give account of the full semantic spectrum of a word but they should rather be accessible, understandable and therefore functional for the largest possible variety of users. Instead of aiming the dictionary at "God's truth" it should rather be aimed at practical and useful approximations. If the semantic component of an article is restricted to a simplified definition, the lack of additional semantic information 
decreases the density of information but it improves the users' chances of better comprehension. Any aspect in a learner's dictionary, even something that is of great importance in other dictionaries, that is detrimental to the users' comprehension of the definition should be abolished.

In spite of its restricted microstructure BA will be an active or encoding learner's dictionary. Although it will not equip its users with all the information which distinguishes a native speaker from a foreign speaker, it is directed at a sound transfer of semantic and pragmatic guidance and this characteristic feature of BA will equip its users with encoding capabilities. Wolski (1991: 2842 ) argues that an active dictionary displays a higher degree of textual compression than its passive counterpart. BA will differ from typical active or encoding dictionaries because of its low density of information, its explicitness and the restricted textual compression. Yet, it presents its microstructural addressing in such a way that the user can apply it in an encoding function. The lower degree of textual compression in BA is motivated by its assignment as instrument in the teaching of Afrikaans as a foreign language. Because of the linguistic and cultural background of the users of BA their primary demand of an encoding dictionary is information on the meaning and correct use of Afrikaans lexical items. The dictionary has to be a functional tool and has to aid its users in the improvement of their communicative skills.

\section{Illustrative examples}

As part of its encoding function BA offers an extensive collection of illustrative examples. According to Wiegand (1988: 581) each example employed in the article of a polysemous lemma should represent only one polysemous sense. Following this idea BA allocates its examples to specific definitions and establishes a complementary relation between the example(s) and the definition. In a COBUILD-style BA's definitions are given as full sentences, strengthening the link between definition and example. In many articles a single polysemous sense gets more than one example. This is motivated by the need to illustrate different uses or stylistic levels in which the word can occur. The examples also help the user to distinguish between semantically related words and nearsynonyms, cf. Walter (1992: 129).

Hansen (1990: 19) regards examples as a formal lexicographical category. Examples can have a variety of functions in a dictionary, cf. Rademeyer (1992). The utilization of this lexicographical category can be aimed at any of these functions; also the pragmatic function. Examples play an important role, both in textreception and textproduction, to illuminate and distinguish different polysemous senses of a lemma, cf. Jehle (1990: 271). BA is not the only dictionary to emphasize the acute pragmatic need for examples in Afrikaans learner's dictionaries. In TAW examples are also awarded a focus position in the 
article. In the Afrikaans-English section each translation equivalent is followed by an English example and its Afrikaans translation:

"draaiz 1. turn [a] The harder you pedal, the faster the wheels turn. Hoe harder jy trap, hoe vinniger draai die wiele. [b] He turned the handle to check whether the door was locked. Hy het die handvatsel gedraai om te kyk of die deur gesluit was...."

Decreasing the density of information by introducing a bidirectional orientated dictionary, a restricted and simplified microstructure with emphasis on the definition/translation equivalent and the use of illustrative examples does not impede the encoding function of a learner's dictionary but rather substantiates its claims of being a most valuable instrument in the enhancement of communicative skills in a foreign language.

\section{Encyclopedic information in learner's dictionaries - a different ap- proach}

One of the traditional disputes in the descriptive lexicography involves the relation between linguistic and encyclopedic information. A strict structuralist approach favours a bias towards pure linguistic information. According to this approach the definition should only contain elements that represent the results of a semantic analysis of the lemma, cf. Gouws (1989: 185-199). A more lenient approach, as professed by cognitive semanticists, allows the definition to include a certain amount of information traditionally regarded as extra-linguistic. Cognitive semanticists argue that a lexical concept includes all the information associated with it, without a distinction between linguistic and encyclopedic information, cf. Geeraerts (1986: 187).

The discussion of the lexicographical representation of encyclopedic information has primarily been concerned with monolingual dictionaries and although a lot of attention has been given to this aspect, there has been no definite solution or a clearly definable distinction between encyclopedic and linguistic information. Zgusta (1971: 198-9) differentiates encyclopedic dictionaries from linguistic ones but he admits that this division is not necessarily an either-or matter because there are encyclopedic elements in almost every dictionary. He even says that some of these encyclopedic elements are unavoidable. Wiegand (1988b: 742-3) states it quite emphatically that it is wrong to differentiate between dictionaries and encyclopedias merely on the basis of a distinction between semantic and encyclopedic information in the lexicographical definition. Like Zgusta he does not regard this distinction as an either-or matter.

Questions about encyclopedic information have been relevant especially to general monolingual dictionaries of a more comprehensive nature. Neither 
the learner's dictionary nor the bilingual dictionary has received much attention as potential containers of this information type. In the relative short history of the learner's dictionary it has been accepted without argument that this typological category has to focus on the typical linguistic information needed by its target users and that this dictionary should contain little extralinguistic information. This approach has been motivated by the microstructural scope of learner's dictionaries. According to Herbst (1990: 1379) the encyclopedic elements of a monolingual dictionary may be of great importance to the native speaker, whereas the foreign learner will be looking for other types of information. This is a valid argument if the encyclopedic information is restricted to the definition. The definition in the learner's dictionary should primarily focus on the meaning of the lemma. However, to improve the pedagogical scope of the learner's dictionary, lexicographers should evaluate different types of microstructural entries in order to ascertain the most efficient ways of conveying information relevant to the learner's needs in his mastering of the foreign language. This might demand innovative approaches and changes in the existing perspectives, and may lead to a reappraisal of the desirability of encyclopedic information in learner's dictionaries and to an embarkation on a more encyclopedic-based approach.

As a potential microstructural category the notion "encyclopedic information" has so far been allocated a very limited scope. The discussion of this type of information in dictionaries has been directed at its occurrence in the definition, with some scant attention to the encyclopedic character of pictorial illustrations. Advocating in favour of encyclopedic information in learner's dictionaries does not necessarily imply a plea for the comprehensive inclusion of this information type in the dictionary definition. Encyclopedic information can be regarded as a separate microstructural category. The lexicographer has to decide how and where to accommodate it in the dictionary article. The acknowledgement of this category does not have to alter the status of encyclopedic features in the definition. As a semantic description the definition in a monolingual dictionary will almost always include some form of encyclopedicity. In this regard the lexicographer could adhere to the arguments of Zgusta (1971: 198-9) and Wiegand (1988b: 742-3) that the differentiation between encyclopedic and linguistic information is not absolute. Yet, the lexicographer has to be able to indicate the permissible extent of the encyclopedic infiltration in the definition. A dictionary definition is aimed at an unambiguous transfer of meaning. One of the most important functions of a learner's dictionary is to enable the potential user to acquire a certain degree of semantic and communicative fluency in the specific language. The amount of encyclopedic information needed to obtain this goal may be included as part of the semantic description, but it should be far less than the cognitive semanticists' idea of all the information associated with a specific lexical,concept.

Treating encyclopedic information as a separate microstructural category would neither impede nor extend the traditional occurrence of this information 
type, but will rather present a new opportunity to utilize encyclopedic features as an additional entry in the overall lexicographical treatment of a lexical item. One of the implications of working with the dictionary article as a text, cf. Wolski (1989), is that the different microstructural elements have to be employed in an interactive relation to one another. Without increasing the degree of textual compression in an article it can be expected from a lexicographer to construct an article in such a way that the different microstructural categories complement each other. This should also apply to the occurrence of an encyclopedic category.

The lack of encyclopedic information in learner's dictionaries gives evidence of inferior research regarding the needs of real language learners as well as the pedagogical assignment and function of a dictionary in the teaching of a foreign language. If the occurrence of encyclopedic information in learner's dictionaries received more attention and had it been at the focus of linguistic and pedagogical research, there would have been far greater recognition of its functional value as part of the overall educational process. Contrary to the belief of Herbst (1990: 1379) that encyclopedic information is not relevant to learners of a foreign language, and in spite of the fact that the inclusion of an encyclopedic component will increase the density of information, the accommodation of this microstructural category could enhance the learner's comprehension because of its explicitness and direct link with the real life experience.

This paper will neither endeavour to define the notion "encyclopedic category" nor discuss its potential nature and extent. Scant attention will be given to one type of entry often regarded as an unnecessary and encyclopedic part of the dictionary article, i.e. the use of pictorial illustrations. It has been mentioned above that Hansen (1990: 19) regards examples as a formal lexicographical category. Examples have, amongst others, a pragmatic function to illustrate the use of a lemma. This function is performed by verbal illustrations. As a formal lexicographical category examples also include a non-verbal component, i.e. pictorial illustrations. These examples are used to illustrate the object to which the lemma refers. Pictorial illustrations perform more than one microstructural function. They are part of at least two categories, i.e. the category of lexicographical examples as well as the encyclopedic category. The latter assignment of pictorial illustrations will be discussed briefly.

\section{The use of pictorial illustrations as part of the encyclopedic category}

Although they are employed quite frequently, pictorial illustrations are too often regarded as ornamental components of a dictionary article. This type of entry is primarily restricted to monolingual dictionaries with a comprehensive approach, where it is employed as a non-essential element which often duplicates the information given in the verbal definition. Dictionary critics have the full right to regard pictorial illustrations as redundant entries if they perform 
no distinctive function. However, the lexicographical validity of their employment is unquestionable when these entries enhance the comprehension of the target user. To achieve this goal in a monolingual dictionary the non-verbal illustrations should complement the verbal definition by giving additional information or by explicating some features which the definition cannot present clearly enough. The use of pictorial illustrations should not be limited to monolingual dictionaries. Examples and encyclopedic information are microstructural categories that should be included in monolingual and bilingual dictionaries. In both these functions pictorial illustrations have to be employed in bilingual dictionaries. In a bilingual dictionary a pictorial illustration can present an ostensive definition of a translation equivalent.

The use of pictorial illustrations display encyclopedic characteristics because of the emphasis on extralinguistic features. Yet they are not redundant entries because they support the pedagogical assignment of the dictionary article by endeavouring an optimal transfer of information relevant to the learner's needs and demands.

\section{Conclusion}

Learner's dictionaries are important instruments in the teaching of a foreign language. Their compilation has to rely on sound theoretical, pedagogical and linguistic principles. For the multilingual South African situation learner's dictionaries are needed to offer access to the different languages. These dictionaries can help to bridge cultural and linguistic gaps and can enhance the communicative competence of the speakers of different speech communities.

\section{References}

\section{Dictionaries}

Bosman, D.B. et al. $1984^{8}$. Tweetalige Woordeboek/Bilingual Dictionary. Cape Town: Tafelberg. Crowther, J. (Ed.). 1992. Oxford Advanced Learner's Dictionary. Oxford: Oxford University Press.

Du Plessis, M. 1993. Tweetalige Aanleerderswoordeboek/Bilingual Leamer's Dictionary. Cape Town: Tafelberg.

Gouws, R.H., F.A. Ponelis and A.E. Feinauer. 1993. Basiswoordeboek van Afrikaans. Pretoria: J.L. van Schaik.

Kotzé, E. and P. Wela. 1991. Afrikanns/Zoeloe Woordeboek met Engelse vertalings. Cape Town: Tafelberg.

Kritzinger, M.S.B. et al. 198613. Groot Woordeboek/Major Dictionary. Pretoria: J.L. van Schaik.

Procter, P. (Ed.). 1978. Longman Dictionary of Contemporary English. Harlow: Longman.

Sinclair, J. (Ed.). 1987. Collins COBUILD English Language Dictionary. London and Glasgow: Collins. 


\section{Other sources}

Alberts, M. and P. Mtintsilana. 1988. Leksikografiese ontleding van Afrikanse en Afrikatale-leksikons. Pretoria: Raad vir Geesteswetenskaplike Navorsing.

Austin, P. (Ed.). 1983. Papers in Australian Linguistics 15: Australian Aboriginal Lexicography. Pacific Linguistics, Series $A$, no 66.

Ayto, J. 1984. The Vocabulary of Definition. Goetz, D. and T. Herbst (Eds.). 1984: 50-62.

Carter, R. 1983. "You look nice and weedy these days!" Lexical Associations, Lexicography and the Foreign Language Leamer. Journal of Applied Language Study 1 (2): 172-189.

Cowie, A. (Ed.). 1987. The Dictionary and the Language Learnet. Tübingen: Max Niemeyer Verlag.

Diab, T. 1990. Pedagogical Lexicography. Tübingen: Max Niemeyer.

Geeraerts, D. 1986. Woordbetekenis. Leuven: Acco.

Goetz, D. and T. Herbst. (Eds.). 1984. Theoretische und praktische Probleme der Lexikographie. München: Max Hueber Verlag.

Gouws, R.H. 1989. Leksikografie. Cape Town: Academica.

Hansen, G.B. 1990. Artikelstruktur im zweisprachigen Wörterbuch. Tübingen: Max Niemeyer.

Hausmann, F.J. 1989. Das Definitionswörterbuch. Hausmann, F.J. et al. (Eds.). 1989-1991: 981-988.

Hausmann, F.J. and H.E. Wiegand. 1989. Component Parts and Structures of General Monolingual Dictionaries: A Survey. Hausmann, F.J. et al. (Eds.). 1989-1991: 328-360.

Hausmann, F.J., O. Reichmann, H.E. Wiegand and L. Zgusta. (Eds.). 1989-1991. Wörterbücher. Dictionaries. Dictionnaires. An Intemational Encyclopedia of Lexicography. Berlin: Walter de Gruyter.

Herbst, T. 1990. Dictionaries for Foreign Language Teaching: English. Hausmann, F.J. et al. (Eds.). 1989-1991: 1379-1385.

Jehle, G. 1990. Das englische und französische Lermerwörterbuch in det Rezension. Tübingen: Max Niemeyer.

Kühn, P. 1990. Das Grundwortschatzwörterbuch. Hausmann, F.J. et al. (Eds.). 1989-1991: 13531364.

Munske, H.H. et al. (Eds.). 1988. Deutscher Wortschatz. Berlin: Walter de Gruyter.

Otto, A.N. 1989. Kriteria vir 'n Afrikaanse Aanleetderwoordeboek. Unpublished D.Litt-thesis. University of Stellenbosch.

Rademeyer, L. 1992. Die funksies van verbale voorbeeldmateriaal in eentalige woordeboeke. Unpublished MA-thesis. University of Stellenbosch.

Snell-Hornby, M. 1987. Towards a Learner's Bilingual Dictionary. Cowie, A. (Ed.). 1987: 159170.

Tickoo, M.L. (Ed.). 1989. Learners' Dictionaries: State of the Art. SEAMEO Regional Language Centre: Singapore.

Tommola, H. et al. (Eds.). 1992. Euralex '92 Proceedings. Universitas Tampere: Tampere.

Walter, E. 1992. Semantic Set-defining: Benefits to the Lexicographer and the User. Tommola, H. et al. (Eds.). 1992: 129-136.

Wiegand, H.E. 1988. Shangai bei Nacht. Wiegand, H.E. 1988a: 521-626.

Wiegand, H.E. 1988a. Wiegand, H.E. Studien zur neuhochdettschen Lexikographie VI. 2. Teilband. Hildesheim: Georg Olms Verlag. 
Wiegand, H.E. 1988b. Was eigentlich ist Fachlexikographie? Munske, H.H. et al. (Eds.). 1988: $729-790$.

Wierzbicka, A. 1983. Semantics and Lexicography: Some Comments on the Warlpiri Dictionary Project. Austin, P. (Ed.). 1983: 135-164.

Wolski, W. 1989. Formen der Textverdichtung im allgemeinen einsprachigen Wörterbuch. Hausmann, F.J. et al. (Eds.). 1989-1991: 956-967.

Wolski, W. 1991. Formen der Textverdichtung im zweisprachigen Wörterbuch. Hausmann, F.J. et al. (Eds.). 1989-1991: 2837-2854.

Zgusta, L. 1971. Manual of Lexicography. The Hague: Mouton.

Zgusta, L. 1989. Idle Thoughts of an Idle Fellow; or, Vaticinations on the Learners' Dictionary. Tickoo, M.L. (Ed.). 1989: 1-9. 